\title{
Evaluation of Two Irrigation Scheduling Methods and Nitrogen Rates on Corn Production in Alabama
}

\author{
Jose Franco Da Cunha Leme Filho $\mathbb{D}^{1},{ }^{1}$ Brenda V. Ortiz, ${ }^{2}$ Kipling S. Balkcom, ${ }^{3}$ \\ Damianos Damianidis, ${ }^{4}$ Thorsten J. Knappenberger, ${ }^{2}$ and Mark Dougherty ${ }^{5}$ \\ ${ }^{1}$ School of Plant \& Environmental Sciences, Virginia Polytechnic Institute and State University, Blacksburg 24061, VA, USA \\ ${ }^{2}$ Department of Crop Soil and Environmental Sciences, Auburn University, Auburn 36849, AL, USA \\ ${ }^{3}$ Agricultural Research Service United States Department of Agriculture, Soil Dynamics Research, Auburn 36849, Al, USA \\ ${ }^{4}$ Soil Water and Crop Management Group, EEA Oliveros-INTA, Oliveros, Pcia. Santa Fe, Argentina \\ ${ }^{5}$ Department of Biosystems Engineering, Auburn University, Auburn 36849, AL, USA
}

Correspondence should be addressed to Jose Franco Da Cunha Leme Filho; jfleme@vt.edu

Received 23 July 2020; Accepted 28 August 2020; Published 15 September 2020

Academic Editor: Allen Barker

Copyright $\odot 2020$ Jose Franco Da Cunha Leme Filho et al. This is an open access article distributed under the Creative Commons Attribution License, which permits unrestricted use, distribution, and reproduction in any medium, provided the original work is properly cited.

\begin{abstract}
Regulations on nutrient application amounts and environmental impacts of fertilizers are promoting advances in agricultural management strategies to optimize irrigation application and $\mathrm{N}$ fertilization in corn. Previous studies have found a relationship between irrigation application, available water in the soil, and $\mathrm{N}$ fertilizer uptake. The objective of this study was to evaluate interactions between two irrigation scheduling methods and four $\mathrm{N}$ rate applications ( 0 -control, 202, 269, and $336 \mathrm{~kg} \mathrm{ha}{ }^{-1}$ ) on grain yield, aboveground biomass, plant $\mathrm{N}$ concentration, $\mathrm{N}$ uptake, and nitrogen use efficiency in corn. The study was conducted at the Tennessee Valley Research and Extension Center (TVREC) during two growing seasons (2014 and 2015). The irrigation scheduling methods consisted of (i) the pan evaporation method, which is based on managing the crop's estimated evapotranspiration (ET) using pan evaporation values and the crop's consumptive water use and (ii) the sensor-based irrigation scheduling method based on soil matric potential values recorded by soil moisture tension sensors installed in the field. Irrigation amounts from both irrigation scheduling methods indicated that less water was applied with the sensor-based method. The different amounts of irrigation applied associated with the two irrigation scheduling methods did not impact grain yield, aboveground biomass, and NUE. In general, NUEs values decreased with increased $\mathrm{N}$ rates, which means that additional $\mathrm{N}$ fertilizer added to the soil was not converted into grain yield or/and adsorbed by plants; therefore, more $\mathrm{N}$ remained in the soil, increasing the risk for environmental problems.
\end{abstract}

\section{Introduction}

The challenge of making farming profitable and minimizing the environmental effects of agriculture has increased the adoption of new technologies and practices to increase crop production efficiency. Regarding corn production, two major factors affecting yield are soil water availability and nitrogen $(\mathrm{N})$ fertilization; therefore, irrigation and $\mathrm{N}$ application are important management factors for producers. Irrigation is a relevant tool in Alabama and this practice has been increasing among farmers, even though the state enjoys average rainfall amounts of about $1422 \mathrm{~mm}$ per year [1]. However, the amount and distribution of rainfall are highly unpredictable because they can vary drastically depending on the year. Rainfed corn production is risky with large variations in yield from one year to the next. In Alabama, even though the number of irrigated harvested acres of cropland increased from 1997 to 2012, only approximately 44 thousand hectares out of the 870 thousand hectares of harvested cropland were irrigated [2]. Lack of water from rainfall and/or irrigation can impact the morpho-physiology of corn in terms of cellular and whole-plant effects [3, 4]. 
Thus, it can result in substantial yield reduction and reasserting the importance of irrigation for consistent corn yields. Meanwhile, $\mathrm{N}$ fertilizer is also crucial for corn production; Qiu et al. [5] stated that $\mathrm{N}$ is the most limiting nutrient for agricultural production; and $\mathrm{N}$ fertilizer is an important component to maximize the yield of most nonlegume crops. Woli et al. [6] evaluated data of corn hybrids from 1960 to 2000 and determined that grain yield increased by $65 \%$ and total plant biomass by $45 \%$ with agronomic optimum $\mathrm{N}$ input.

Several approaches, such as improved irrigation technologies that include variable rate irrigation and more efficient irrigation scheduling methods, can be adopted by farmers for more effective use of limited water supplies to maximize water use efficiency (WUE) [7, 8]. The aim of an efficient irrigation scheduling program is to optimize the WUE, replenishing the water deficit within the root zone while minimizing $\mathrm{N}$ leaching below this depth [9]. Currently, multiple irrigation scheduling methods have been developed to help producers maintaining adequate soil water content levels in the root zone. Technological advances have improved the devices that continuously monitor changes in soil moisture status. These devices are able to monitor soil moisture during and after irrigation; also they control the amount of water applied. Phene and Howell [10] confirmed that irrigation systems can be controlled accurately with sensors that monitor the soil matric potential within the root zone. There are, however, simpler methods to conduct irrigation scheduling. The pan evaporation method using the data from weather stations can be the simplest, cheapest, and most practical meteorological method to measure local atmospheric evaporation demand [11]. Additionally, values obtained using the pan evaporation method are important references for water resource assessment and monitoring evaporative climate change [12]. It is recognized that the adoption of appropriate irrigation scheduling practices could increase or maintain yields and maximize profit for producers. Also, the water savings can reduce the risk of overirrigation and environmental impacts and consequently improving agricultural sustainability [13].

Nitrogen fertilization indicates that the highest yield increasing effect for corn on different soils occurs when the three macroelements (NPK) are considered [14, 15]. Many physiological processes associated with corn development are enhanced with $\mathrm{N}$ fertilization [16]. Variation in $\mathrm{N}$ application affects crop growth and yield components like potential kernel set [17]. Numerous studies have shown that $\mathrm{N}$ fertilization is highly correlated with corn growth; thus, lower $\mathrm{N}$ supply can promote the reduction of plant height, leaf area index (LAI), crop photosynthetic rate, radiation use efficiency, and plant $\mathrm{N}$ uptake [18-20].

The integration of effective water and fertilizer management strategies is essential for increasing crop production and maximizing the economic net return while sustainability is maintained [16, 21-23]. Management strategies for water and $\mathrm{N}$ can minimize crop production costs and environmental impacts while maintaining crop performance and economic returns [24]. Efficient $\mathrm{N}$ utilization to obtain high yields requires adequate water supply for the crop. For instance, a reduction in plants transpiration as a result of water stress can cause decrease in N uptake [25], including reduced development of steam and leaf cells [26]. On the other hand, a surplus of irrigation and $\mathrm{N}$ fertilizer can increase residual soil $\mathrm{NO}_{3}-\mathrm{N}$ and it may leach or denitrify [27], reducing the efficiency of applied N. Studies have demonstrated that crop growth and yield response to $\mathrm{N}$ fertilization varies under different water management conditions. However, there are few studies addressing interactions between $\mathrm{N}$ management strategies and the soil water status in Alabama. Therefore, studies to understand $\mathrm{N}$ uptake dynamics and determine the best $\mathrm{N}$ management practices under two different irrigation scheduling methods are important to help Alabama producers optimize corn yields and avoid adverse environmental impacts. The objectives of this study were (1) to determine the effects of two irrigation scheduling methods, pan evaporation, and sensorbased scheduling, on $\mathrm{N}$ supply on corn $\mathrm{N}$ uptake, (2) to evaluate the interaction of irrigation scheduling methods and $\mathrm{N}$ on Nitrogen Use Efficiency (NUE), and (3) to assess the impact of different $\mathrm{N}$ rates on corn yield and NUE.

\section{Materials and Methods}

2.1. Site Description. The field experiment was conducted at Tennessee Valley Research and Extension Center located in Belle Mina, Alabama ( $34^{\circ} 39^{\prime} 24^{\prime \prime} \mathrm{N} 86^{\circ} 52^{\prime} 45^{\prime \prime} \mathrm{W}, 183 \mathrm{~m}$ above mean sea level) during the 2014 and 2015 growing seasons. The dominant soil series at the research site is a Decatur silty clay loam (fine, kaolinitic, thermic Rhodic Paleudults) with $0 \%$ to $10 \%$ slope [28]; rainfall conditions during both growing seasons (April-August) were below the 30-year average (1971-2000) according to the experimental station data. Total rainfall during the 2014 growing season was $11 \mathrm{~mm}$ below average and $19 \mathrm{~mm}$ below average in 2015 . However, in 2014, rainfall distribution per month with respect to the historic average (1971-2000) was higher in April $(+39 \mathrm{~mm})$ and June $(+42 \mathrm{~mm})$, but rainfall in May $(-50 \mathrm{~mm})$, July $(-13 \mathrm{~mm})$, and August $(-29 \mathrm{~mm})$ was below average. In 2015, above normal rainfall with respect to the 30 -year average was observed in April $(+21 \mathrm{~mm})$ and May $(+6 \mathrm{~mm})$ contrasting with rainfall in June $(-21 \mathrm{~mm})$, July $(-1 \mathrm{~mm})$, and August $(-24 \mathrm{~mm})$ that was below average.

2.2. Experimental Design. A split-plot design with three replications was implemented for this study in which irrigation regime was the main plot and $\mathrm{N}$ fertilizer rates were the subplots. Two irrigation scheduling methods (pan evaporation method and sensor-based irrigation method), and four $\mathrm{N}$ rates ( 0 -control, 202, 269, and $336 \mathrm{~kg} \mathrm{ha}^{-1}$ ) were tested for plant $\mathrm{N}$ uptake, NUE, and yield differences. Plots consisted of eight rows $11.8 \mathrm{~m}$ long and $5.3 \mathrm{~m}$ wide with a row spacing of $76.2 \mathrm{~cm}$ and the seeding rate was 89,000 plants $\mathrm{ha}^{-1}$. Urea ammonium nitrate (UAN 32-0-0) was used as the fertilizer source, which was split applied with $1 / 3$ of the total applied at planting and the remainder in a sidedress application at the V6 growth stage. Each eight-row plot was divided in half, 4 rows received 202, 269, or 
$336 \mathrm{~kg} \mathrm{Nha}^{-1}$ depending on the randomization, and the other adjacent 4 rows did not receive any $\mathrm{N}$ which allowed for NUE estimation. Plots received $224.1 \mathrm{~kg} \mathrm{ha}^{-1}$ in a preplant application of $\mathrm{P}$ and $\mathrm{K}$. All the cultural practices were performed according to Alabama Cooperative Extension System (ACES) recommendation to maximize corn yield. Each plot was independently irrigated with four overhead sprinkler nozzles located in each corner of the plot.

According to ACES, the recommended $\mathrm{N}$ rate for irrigated corn in the state is $224.1 \mathrm{~kg} \mathrm{ha}^{-1}$ in order to achieve $11299 \mathrm{~kg} \mathrm{ha}^{-1}$ yield. If the yield goal is greater than $12555 \mathrm{~kg} \mathrm{ha}^{-1}$, the $\mathrm{N}$ recommendation is to apply $1 \mathrm{~kg}$ of $\mathrm{N}$ per $45.3 \mathrm{~kg}$ of anticipated corn yield [29]. The Pioneer 1690 YHR corn hybrid was planted on April $4^{\text {th }}$ in 2014 and April $24^{\text {th }}$ in 2015 in single rows and managed with conservation tillage and rye (Secale cereale) cover crop. In both growing seasons, the cover crop was planted on 11/21/13 and $11 / 07 / 14$, respectively. It received $33.6 \mathrm{~kg} \mathrm{ha}^{-1}$ of $\mathrm{N}$ fertilizer (UAN 32-0-0) in both seasons to maximize biomass production.

2.3. Water Management Treatments. Two irrigation scheduling methods tested in our study differed from each other in the way to estimate the amount of water stored in the soil during the growing season. The pan evaporation method was based on calculating the crop's estimated evapotranspiration (ET) using the pan evaporation values and the crop's consumptive water use. On the other hand, the sensor-based irrigation relied on measurements of soil matric potential provided by sensors in order to apply the correct amount of irrigation at the right time. The water use efficiency (WUE) of the two irrigation scheduling methods was included in our evaluation to establish differences in the total amount of water applied in the plots.

\subsubsection{Pan Evaporation Irrigation Scheduling. Daily pan} evaporation data was reported from the weather station located at the research site (http://www.awis.com). The daily irrigation requirement, ET, was calculated using the following equation: $\mathrm{ET}=0.90 \times \mathrm{PAN} \times \mathrm{CC}$ where evapotranspiration, ET $\left(\mathrm{mm} \mathrm{day}{ }^{-1}\right)$, was calculated from $90 \%$ pan evaporation, PAN (mm day ${ }^{-1}$ ) adjusted for fractional canopy cover (CC) [30, 31]. Canopy cover was determined weekly by measuring the open canopy distance $(\mathrm{cm})$ between rows with a tape measure. Fractional canopy cover was calculated using the following formula: (row width open canopy distance)/row width. Canopy closure measurements were a critical component used in this study to determine the daily amount of irrigation water. Rainfall was not accounted for in the equation because calculated pan evaporation values on cloudy and rainy days decreased considerably, so this method accounts for rainfall without directly subtracting rainfall from irrigation amounts. Thus, irrigation was applied based on the above equation, replacing water lost by evapotranspiration. Soil moisture sensors were not used as a tool to schedule irrigation with pan evaporation plots. However, some sensors were installed in the pan evaporation plots in order to monitor soil water dynamics.

2.3.2. Sensor-Based Irrigation Scheduling. Irrigation events in the sensor-based irrigation scheduling plots were conducted using information from the soil water tension sensors installed between two corn plants in the experimental area. The smart sensor array system used in our research consisted of a centrally located receiver connected to a laptop computer and multiple sensor nodes installed in the field. Each sensor node consisted of sensors (3 soil moisture sensors-Watermark ${ }^{\circledR}$ ) and thermocouples, a sensor circuit board, and an active transmitter, which transmitted data to the receiver [32]. The smart sensor board acquired sensor values and wirelessly transmitted those values to a centrally located radio frequency receiver, and then via cellphone signal, the data was transmitted to a website. The board of each node was able to read up to three Watermark ${ }^{\circledR}$ granular resistive-type soil moisture sensors located at three soil depths $(15,30$, and $60 \mathrm{~cm})$ enabling a better assessment of the water availability through the soil profile. In terms of water adsorption, these three soil depths corresponded to the most active root zone in corn. A Watermark ${ }^{\circledR}$ sensor is a granular matrix device that was used to measure soil water tension; therefore the data obtained from the Watermark ${ }^{\circledR}$ sensors is transferred to the database in Kilopascal units. These soil water tension measuring devices provided a continuous measurement analogous to the force (soil matric potential) necessary for corn plants to extract water from the soil and these values were used to schedule irrigation. Watermark ${ }^{\circledR}$ sensors have been used to measure soil water status for irrigation management and other purposes for more than two decades [33-36].

2.3.3. Soil Water Dynamics and Irrigation Strategy. Though soil moisture sensors provided hourly data of soil matric potential in the field, the next important step was to set the Management Allowed Depletion (MAD) which is how much water to decrease from the soil before starting irrigation. The MAD represented the level of plant available water (PAW) used by the plant or evaporated before irrigation was applied without exposing the plants to water stress. Several studies have recommended irrigating row crops such as corn or cotton (Gossypium hirsutum L.) when the MAD approaches 50\% [37-39]. On the other hand, Irmak et al. [40] used 35\% depletion of PAW in a study testing irrigation strategies based on soil matric potential sensors. Therefore, as it was the first time that this type of experiment was conducted in Alabama, a MAD of 35\% was selected as a more conservative approach. Once the MAD in volumetric water content units was identified, it was necessary to identify the soil matric potential that corresponded with the specific MAD value. In order to define this MAD, soil water level, it was necessary to estimate first the field capacity (FC), permanent wilting point (PWP), and PAW values, which were important parameters to determine the soil moisture threshold to start irrigation on the sensorbased irrigation plots. Soil texture data from the soil samples 
collected from the study site was used to calculate a pedotransfer function which was used to estimate soil water retention curves (SWRC) and subsequently the FC and PWP parameters. Saxton et al. [41] stated that experiences have shown that soil texture predominately determines the waterholding characteristics of most agricultural soils.

Disturbed soil samples were collected from three depths $(15,30$, and $60 \mathrm{~cm})$ in a representative area of the field. The disturbed soil samples were used to run a soil texture analysis, which allowed for estimation of the percentage of sand, silt, and clay for each sample. These data were used to estimate the van Genuchten equation parameters using the retention curve (RECT) computer program. The percent of sand, silt, and clay data were input in the (RETC) computer program; thus this software defined the $\theta_{\mathrm{r}}, \theta_{\mathrm{s}}, \alpha$, and $n$ values representing the experimental field. All these variables were plugged in the van Genuchten equation. The van Genuchten model has the following form:

$$
\theta_{h}=\theta_{r}+\frac{\theta_{s}-\theta_{r}}{\left(1+(\alpha h)^{n}\right)^{m}}
$$

where $\theta(h)$ is the actual soil water content $\left(\mathrm{cm}^{3} \mathrm{~cm}^{-3}\right)$ at the suction $h\left(\mathrm{~cm}\right.$, taken positive for increasing suctions); $\theta_{\mathrm{r}}$ and $\theta_{\mathrm{s}}$ are the residual and saturated soil water contents $\left(\mathrm{cm}^{3}\right.$ $\mathrm{cm}^{-3}$ ), respectively; $\alpha$ is a parameter related to the inverse of the air entry suction $\left(\mathrm{cm}^{-1}\right)$; and $m$ and $n$ are curve shape parameters [42]. Note that $m$ here characterizes the asymmetry using the constraint $m=1-^{-} 1 / n$; therefore the water retention characteristics defined by this equation only contained four unknown parameters that were $\theta_{\mathrm{r}}, \theta_{\mathrm{s}}, \alpha$, and $n$ and these unknown parameters were defined using the (RETC) computer program (Table 1). The solution of this equation provided enough data to generate the SWRC representing the soil water content according to the soil matric potential, which was essential to set the irrigation threshold (Figure 1).

Each SWRC was generated in order to estimate the amount of water retained in a soil (expressed as mass or volume water content) under equilibrium at a given soil matric potential. In practical applications, soil matric potential has a negative sign (i.e., more negative soil matric potential values indicate drier soil); however, a positive sign is used in this study as an indicator of soil water tension.

Once the SWRC was generated, the FC and PWP were identified. These parameters are the key for the PAW estimation. Richards and Weaver [43] found that a coarsetextured soil can reach FC at $10 \mathrm{kPa}$ and a fine-textured soil can reach FC at $33 \mathrm{kPa}$. The PWP is usually found at a soil matric potential of $1500 \mathrm{kPa}$. Therefore, for the purpose of this study, soil matric potential values representing the FC were selected based on soil texture. In most cases, a FC value at $33 \mathrm{kPa}$ was used in this study when the soil textural class in the experimental field was silty clay loam, silty clay, or clay (Tables 1 and 2).

The FC and PWP were established; thus the plant available water (PAW) was calculated using FC minus PWP (Table 2). Once PAW was calculated, the irrigation threshold was set using the MAD value of $35 \%$. The specific soil matric
TABle 1: van Genuchten equation parameters from 2014, percentage (sand, silt, and clay), and soil textural class for three soil depths at the TVREC. The parameters from 2014 were used during both growing seasons.

\begin{tabular}{lccc}
\hline Depth $(\mathrm{cm})$ & $0-15$ & $15-30$ & $30-60$ \\
\hline$\theta_{\mathrm{r}}{ }^{\ddagger}$ & 0.0808 & 0.0969 & 0.1048 \\
$\theta_{\mathrm{s}}{ }^{\mathrm{S}}$ & 0.4095 & 0.4779 & 0.536 \\
$\alpha^{g}$ & 0.089 & 0.0132 & 0.0178 \\
$N^{£}$ & 1.4669 & 1.365 & 1.3098 \\
$m^{\mathrm{a}}$ & 0.3183 & 0.2674 & 0.2365 \\
$\theta_{\mathrm{s}}-\theta_{\mathrm{r}}{ }^{\ddagger}$ & 0.3287 & 0.381 & 0.4312 \\
$\%$ sand & 16.18 & 10 & 9.76 \\
$\%$ silt & 51.05 & 43.45 & 35.74 \\
$\%$ clay & 32.77 & 46.55 & 54.5 \\
Textural class & Silty clay loam & Silty clay & Clay \\
\hline
\end{tabular}

${ }^{\ddagger}$ Residual soil water content $\left(\mathrm{cm}^{3} \mathrm{~cm}^{-3}\right)$. ${ }^{\S}$ Saturated soil water content $\left(\mathrm{cm}^{3}\right.$ $\left.\mathrm{cm}^{-3}\right)$. 'Parameter related to the inverse of the air entry suction $\left(\mathrm{cm}^{-1}\right)$; ${ }^{E_{n}}$ curve shape parameters (empirical parameter). ${ }^{a} m=(1-1 / n) .{ }^{¥} \theta_{\mathrm{r}}$ and $\theta_{\mathrm{s}}$ are the residual and saturated soil water contents $\left(\mathrm{cm}^{3} \mathrm{~cm}^{-3}\right)$.

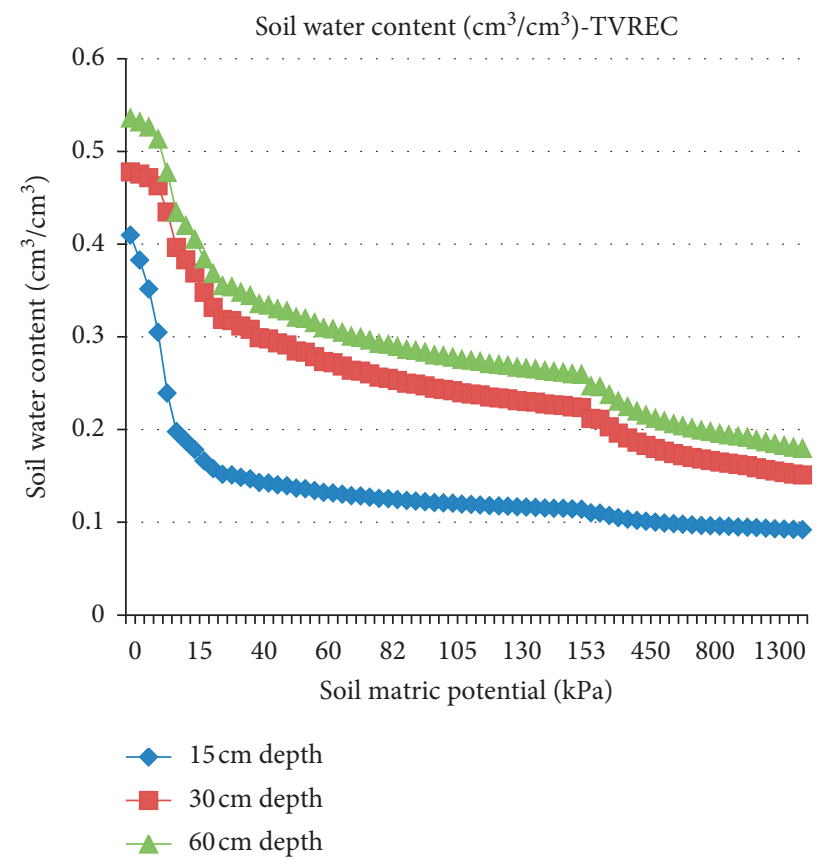

Figure 1: Soil water retention curves created using the van Genuchten equation for each depth $(15,30$, and $60 \mathrm{~cm})$ to convert the soil water content data into soil matric potential in 2014 and 2015 at TVREC.

potential (tension) representing the irrigation threshold was equal to $76 \mathrm{kPa}$, which was the average value of the three soil depths (Table 2). Every time the sensors installed on the sensor-based irrigation plots were approaching $76 \mathrm{kPa}$, an irrigation event was triggered. A weighted average of the sensor values located at the three different depths was used and it changed according to the corn growth stage. At the beginning of the season, the upper sensor $(15 \mathrm{~cm}$ depth) had more importance as a parameter to schedule irrigation events because corn roots have not reached the deeper layers of the soil. However, as the season progressed, the average of 
TABLE 2: Field capacity, permanent wilting point, plant available water, water depletion, and 35\% depletion of plant available water in water content and soil matric potential units for each soil depth at TVREC in 2014. Parameters from 2014 were used during both growing seasons.

\begin{tabular}{|c|c|c|c|}
\hline Depth $(\mathrm{cm})$ & $0-15$ & $15-30$ & $30-60$ \\
\hline Field capacity $(\mathrm{FC})^{\ddagger}$ & 0.1481 & 0.3115 & 0.3478 \\
\hline Permanent wilting point $(\mathrm{PWP})^{\S}$ & 0.0921 & 0.1517 & 0.1806 \\
\hline Plant available water (PAW) & 0.056 & 0.1598 & 0.1672 \\
\hline Water depletion $(35 \%)\left(\mathrm{cm}^{3} / \mathrm{cm}^{3}\right)^{£}$ & 0.0196 & 0.0559 & 0.0585 \\
\hline $35 \%$ of PAW $\left(\mathrm{cm}^{3} / \mathrm{cm}^{3}\right)^{a}$ & 0.1285 & 0.2555 & 0.2892 \\
\hline $35 \%$ of PAW $(\mathrm{kPa})^{¥}$ & 70 & 80 & 83 \\
\hline
\end{tabular}

${ }^{\ddagger}\left(\mathrm{cm}^{3} \mathrm{~cm}^{3}\right),{ }^{\$}\left(\mathrm{~cm}^{3} \mathrm{~cm}^{3}\right),{ }^{9} \mathrm{PAW}=\mathrm{FC}-\mathrm{PWP},{ }^{E}$ water depletion $(35 \%)=\mathrm{PAW},{ }^{*} 0.35-35 \%$ was the soil water depletion selected in the study, ${ }^{\mathrm{a}} 35 \%$ of PAW $\left(\mathrm{cm}^{3} \mathrm{~cm}^{3}\right)=\mathrm{PAW}$ - water depletion $(35 \%)$, and ${ }^{\ddagger} 35 \%$ of PAW $(\mathrm{kPa})=$ soil matric potential referred to the depletion of $35 \%$ of PAW.

the three sensor tension values was used. Dates and amounts of irrigation events for both pan evaporation method and sensor-based irrigation plots were registered; also each irrigation event did not exceed 15 to $25 \mathrm{~mm}$ in order to avoid runoff. Sensors located in the pan evaporation plots were also monitored; however, the irrigation trigger was not based on sensor values but on the method described previously.

2.4. Nitrogen Rate Management Treatments. Three $\mathrm{N}$ rates $\left(202,269\right.$, and $\left.336 \mathrm{~kg} \mathrm{~N} \mathrm{ha}^{-1}\right)$ and the control $\left(0 \mathrm{~kg} \mathrm{Nha}^{-1}\right)$ were evaluated under the two irrigation methods in order to observe the impact of different $\mathrm{N}$ rates and irrigation practices including their interaction on corn yield, $\mathrm{N}$ uptake, and NUE. Aboveground biomass samples were collected at harvest to determine $\mathrm{N}$ concentration in the grain and stover and then establish the impact of different $\mathrm{N}$ rates on NUE.

2.5. Field Data Collection and Data Analysis. At maturity, corn plants were harvested from two $1 \mathrm{~m}$ row sections of each plot. Samples were harvested from rows 1 and 4 because the middle two rows were harvested for yield data using the plot combine. Harvested plants were separated in ears and stover (stem + leaves); then the stover was weighted at the field and a subsample was collected. The ears and stover subsamples were oven-dried at $60^{\circ} \mathrm{C}$ for one week to reach a constant weight. Also, the ears were shelled prior to $\mathrm{N}$ analyses. Posteriorly, the grain, cob, and stover were ground through a $2 \mathrm{~mm}$ sieve and analyzed for total $\mathrm{C}$ and $\mathrm{N}$ with the $\mathrm{LECO}^{\mathrm{R}} \mathrm{C} / \mathrm{N}$ analyzer (LECO Corp., St. Joseph, MI).

The two center rows were harvested using a plot combine, and the grain yield was based on the data provided by the combine. The stover yield was the sum of cob and stalk yield. Stalk yield was calculated based on the fresh stalk yield harvested in $2 \mathrm{~m}$ row and the proportional oven-dried stalk yield in the subsample. Cob yield was calculated based on total weight of oven-dried cobs after the grain was shelled. Grain yield, aboveground biomass, plant $\mathrm{N}$ concentration, and plant $\mathrm{N}$ uptake are reported on an oven-dried basis.

For each plot, the aboveground $\mathrm{N}$ uptake, recovery efficiency $\left(R_{n}\right)$, nitrogen agronomic efficiency $\left(A E_{n}\right)$, nitrogen internal efficiency $\left(\mathrm{IE}_{\mathrm{n}}\right)$, and nitrogen partial productivity $\left(\mathrm{PFP}_{\mathrm{n}}\right)$ values were calculated using the following equations:

aboveground $\mathrm{N}$ uptake $=($ grain $\mathrm{N}$ concentration $\times$ grain yield $)+($ Stover $\mathrm{N}$ concentration $\times$ Stover biomass $)$,

$$
\begin{aligned}
\mathrm{REN} & =\frac{\left(U_{\mathrm{N}}-U_{0}\right)}{\mathrm{N} \text { rate }} \times 100 \%, \\
\mathrm{AEN} & =\frac{\left(Y_{\mathrm{N}}-Y_{0}\right)}{\mathrm{N} \text { rate }}, \\
\mathrm{IEN} & =\frac{Y_{\mathrm{N}}}{U_{\mathrm{N}}}, \\
\text { PFPN } & =\frac{Y_{\mathrm{N}}}{\mathrm{N} \text { rate }},
\end{aligned}
$$

where $U_{\mathrm{N}}$ and $Y_{\mathrm{N}}$ represented the $\mathrm{N}$ uptake by aboveground biomass and grain yield in the fertilized treatments, respectively, and $\mathrm{U}_{0}$ and $\mathrm{Y}_{0}$ represented the $\mathrm{N}$ uptake by aboveground biomass and grain yield in the control treatments, respectively. The $\mathrm{N}$ rate was the total amount of $\mathrm{N}$ applied during the corn growing season. The NUE was calculated using four different formulas in order to evaluate the interaction between yield and $\mathrm{N}$ uptake as $\mathrm{N}$ rate change.

2.6. Statistical Analysis. Yield, aboveground biomass, grain $\mathrm{N}$ concentration, stover $\mathrm{N}$ concentration, grain $\mathrm{N}$ uptake, aboveground $\mathrm{N}$ uptake, $\mathrm{RE}_{\mathrm{n}}, \mathrm{AE}_{\mathrm{n}}, \mathrm{IE}_{\mathrm{n}}$, and $\mathrm{PFP}_{\mathrm{n}}$ differences 
among $\mathrm{N}$ rates were analyzed for both years of the study and for each irrigation scenario (pan evaporation irrigation scheduling method and sensor-based irrigation scheduling). The statistical analysis was conducted using the procedure for generalized linear mixed models (PROC GLIMMIX) implemented in SAS 9.1 (SAS for Windows v. 9.1, SAS Institute Inc., Cary, NC). All dependent variables were first analyzed to measure the effect of the irrigation scheduling methods, $\mathrm{N}$ rates, and years as fixed effects. It allowed us to measure the magnitude of irrigation method $\times \mathrm{N}$ rate $\times$ years interactions. Preliminary analyses suggested the need for treating years as nonfixed effect in order to observe the effects of each year independently and scheduling methods and $\mathrm{N}$ rates as fixed effects. The mean separation between irrigation methods, $\mathrm{N}$ rates, years, and all the interactions were obtained by Tukey's significant difference test $(P<0.05)$.

\section{Results and Discussion}

3.1. Climatic Conditions and Irrigation Performance. Monthly average weather variables for the 2013, 2014, and 2015 growing seasons including the long-term average values (1971-2000) are summarized in Table 3. Overall, climatic conditions helped explain differences in irrigation amount and grain yield. Differences in rainfall and temperature influence crop evapotranspiration in a given environment. Runge [44] found that daily temperature and rainfall affect corn yield from 25 days before to 15 days after anthesis. The seasonal average temperature was $22.60^{\circ} \mathrm{C}$ and $23.50^{\circ} \mathrm{C}$ in 2014 and 2015 , respectively. The seasonal total rainfall in 2014 and 2015, respectively, was $502 \mathrm{~mm}(2.1 \%$ below normal) and $495 \mathrm{~mm}$ (3.7\% below normal). The total rainfall was relatively similar across the two years and slightly below the (30 years) normal, which was $513 \mathrm{~mm}$. However, rainfall distribution through the growing season will have greater effect on irrigation amount than total rainfall. Thus, if rainfall is concentrated in the period of high-water demand, irrigation requirements will be reduced and if rainfall is concentrated at the beginning and the end of the season, it will also limit irrigation requirements. In this study, rainfall was distributed differently before and after tasseling in 2014 but evenly in 2015. According to Lee (2011), tasseling is the highest corn water demand period. In 2014 and $2015,41 \%$ and $58 \%$ of total rainfall and $49 \%$ and $51 \%$ of the total rainfall were evenly distributed before and after tasseling, respectively.

3.2. Irrigation Amounts. Average irrigation amounts applied in the sensor plots were $106 \mathrm{~mm}$ and $142 \mathrm{~mm}$ in 2014 and 2015, respectively. However, the temporal distribution of rainfall between the two growing seasons was not comparable. Rainfall in the 2014 growing season was concentrated after tasseling, $294 \mathrm{~mm}$, and in 2015, the rainfall distribution was similar before and after tasseling, $246 \mathrm{~mm}$ and $248 \mathrm{~mm}$, respectively. Thus, considering that after tasseling corresponds to a period of greater water demand in corn, consequently, the 2015 season received much irrigation.
Irrigation amounts for the two irrigation scheduling methods indicated that the sensor-based method received less irrigation during both growing seasons. The 2014 growing season received $138 \mathrm{~mm}$ of irrigation water on the plots under the pan evaporation irrigation scheduling method and the sensor-based irrigation scheduling method received $122 \mathrm{~mm}$ in the plots fertilized with $202 \mathrm{~kg} \mathrm{Nha}^{-1}$ and $99 \mathrm{~mm}$ in the plots fertilized with 269 and $336 \mathrm{~kg} \mathrm{~N} \mathrm{ha}^{-1}$. In 2015, the pan evaporation plots received $215 \mathrm{~mm}$ of irrigation and the sensor-based treatments received $152 \mathrm{~mm}$ at 202 and $336 \mathrm{~kg} \mathrm{Nha}^{-1}$ plots and $127 \mathrm{~mm}$ at $269 \mathrm{~kg} \mathrm{Nha}^{-1}$ plots (Table 4).

Figures 2 and 3 illustrate soil water dynamics in the pan evaporation and sensor-based plots during the 2015 growing season, respectively. Daily soil matric potential data in the figures was collected from sensors installed in the plots fertilized with $269 \mathrm{~kg} \mathrm{Nha}^{-1}$. The figures show how irrigation and rainfall affected soil matric potential values. From the pan evaporation method, it was possible to observe that even though a specific irrigation threshold was not set, the soil matric potential was maintained below $76 \mathrm{kPa}$, at approximately $50 \mathrm{kPa}$, due to more frequent irrigation events (Figure 2). In the sensor-based approach, the irrigation events were applied when the soil matric potential approached the threshold $(76 \mathrm{kPa})$ (Figure 3$)$. Therefore, since soil matric potential was maintained at lower values in the pan evaporation method, it infers that the soil had higher moisture during the growing season. Also, the sensor-based method depleted more water from the soil for irrigation events scheduled at a higher soil matric potential. After July 22 , malfunctions occurred mainly in the sensors located in the 30 and $60 \mathrm{~cm}$ depth in this treatment (sensor-based irrigation fertilized with $269 \mathrm{~kg} \mathrm{~N} \mathrm{ha}^{-1}$ ). However, irrigation practices in the sensor-based irrigation were continued using the shallowest sensor.

3.3. Irrigation Scheduling Methods Effects: Pan Evaporation and Sensor-Based Irrigation. Differences between pan evaporation and sensor-based method were not significant with respect to all parameters analyzed in this study, except for $\mathrm{RE}_{\mathrm{n}}$ (Table 5). Therefore, different amounts of irrigation applied using the two irrigation scheduling methods did not result in significant interactions among treatments that include irrigation $(\mathrm{IxN}, \mathrm{IxY}$, and $\mathrm{IxNx}$ ) for examined variables during 2014 and 2015.

Grain yield is important indicator of profitability for farmers and there were not differences between irrigation methods when these variables were analyzed (Table 5). During both growing seasons, pan evaporation scheduling method on average used $29 \%$ more water than sensor-based irrigation method. In 2014, the average reduction of water applied was $30 \mathrm{~mm}$ and, in 2015, the average reduction of water applied was $71 \mathrm{~mm}$ without statistically significant differences in grain yield or aboveground biomass within each year (Table 4). Based on the 2014 USDA Crop Production Summary (http://www.usda.gov), the nonirrigated corn yield average in the state of Alabama was $9.97 \mathrm{Mg} \mathrm{ha}^{-1}$ and the yield average obtained from the fertilized treatments 
TABLE 3: Monthly average climatic conditions, during the 2013, 2014, and 2015 growing seasons and long-term average values (30 years) measured at the research site TVREC.

\begin{tabular}{|c|c|c|c|c|}
\hline Month & Rainfall $(\mathrm{mm})$ & Temperature max $\left({ }^{\circ} \mathrm{C}\right)$ & Temperature $\min \left({ }^{\circ} \mathrm{C}\right)$ & Average temperature $\left({ }^{\circ} \mathrm{C}\right)$ \\
\hline \multicolumn{5}{|l|}{2013} \\
\hline April & 48 & 22 & 10.3 & 15.9 \\
\hline May & 59 & 25.8 & 14.5 & 16 \\
\hline June & 30 & 31.5 & 19.8 & 25.2 \\
\hline July & 106 & 30.6 & 20.6 & 25.2 \\
\hline August & 15 & 30.7 & 20.1 & 24.6 \\
\hline Total/average & 259 & 28.1 & 17.1 & 21.4 \\
\hline \multicolumn{5}{|l|}{2014} \\
\hline April & 147 & 23.3 & 10 & 16.9 \\
\hline May & 61 & 27.6 & 15.2 & 21.2 \\
\hline June & 151 & 31 & 20.3 & 25 \\
\hline July & 93 & 31 & 19.3 & 24.9 \\
\hline August & 50 & 32.7 & 19.8 & 25.5 \\
\hline Total/average & 502 & 29.1 & 16.9 & 22.6 \\
\hline \multicolumn{5}{|l|}{2015} \\
\hline April & 129 & 23.3 & 11.9 & 17.9 \\
\hline May & 117 & 27.9 & 15.6 & 21.5 \\
\hline June & 88 & 32.3 & 20.6 & 26.1 \\
\hline July & 105 & 33.1 & 22 & 27.2 \\
\hline August & 55 & 31.2 & 19.8 & 24.9 \\
\hline Total/average & 494 & 29.6 & 17.9 & 23.5 \\
\hline \multicolumn{5}{|c|}{ Historic average (1971-2000) } \\
\hline April & 108 & 22.2 & 8.3 & 15.3 \\
\hline May & 111 & 26.7 & 13.6 & 20.1 \\
\hline June & 109 & 30.6 & 17.9 & 24.3 \\
\hline July & 106 & 32.4 & 20 & 26.2 \\
\hline August & 79 & 32.1 & 18.9 & 25.5 \\
\hline Total/average & 513 & 28.8 & 15.7 & 22.3 \\
\hline
\end{tabular}

TABLE 4: Seasonal irrigation on corn under different irrigation scheduling methods and $\mathrm{N}$ rates in 2014 and 2015 at TVREC.

\begin{tabular}{lccc}
\hline & \multicolumn{3}{c}{ Irrigation amount $(\mathrm{mm})$} \\
& 2014 & 2015 \\
\hline & \multicolumn{3}{c}{ Pan evaporation } \\
202 & 138 & & 215 \\
269 & 138 & & 215 \\
336 & 138 & & 215 \\
& 138 & & 215 \\
0 & & Sensor-based \\
202 & $\mathrm{BNIS}^{\ddagger}$ & & $\mathrm{BNIS}$ \\
269 & 122 & & 152 \\
336 & 99 & & 127 \\
\hline
\end{tabular}

${ }^{\ddagger}$ Based on neighboring plot irrigation scheduling (BNIS).

of both irrigation methods was $13.84 \mathrm{Mgha}^{-1}$ and $13.18 \mathrm{Mg} \mathrm{ha}^{-1}$ during the 2014 and 2015 growing seasons, respectively. Glass et al. [45] conducted an evaluation of corn hybrids also at the Tennessee Valley research station and the irrigated corn yield average was $13.99 \mathrm{Mg} \mathrm{ha}^{-1}$.

3.4. Effects of $N$ Rate on Corn Grain Yield and Aboveground Biomass. Significant grain yield differences were observed with respect to $\mathrm{N}$ rate, year, and interaction of year $\times \mathrm{N}$ rate (Table 5). In contrast, there was no aboveground biomass differences observed with respect to the same factors (Table 5). The lowest grain yield was observed on the control treatment during both years (Table 6). In 2014, the greatest grain yield was $14.23 \mathrm{Mg} \mathrm{ha}^{-1}$ achieved in the plot fertilized with $269 \mathrm{~kg} \mathrm{ha}^{-1}$ and, in 2015, the greatest yield was $13.81 \mathrm{Mgha}^{-1}$ achieved in the plot fertilized with $336 \mathrm{~kg} \mathrm{Nha}^{-1}$ (Table 6). In 2014, grain yield differences between the control and fertilized treatments were statistically significant; however no statistical differences were found between the fertilized plots (Table 6). In other words, the increase of $\mathrm{N}$ rate from 202 to $336 \mathrm{~kg} \mathrm{Nha}^{-1}$ did not statistically change grain yield. However, the growing season of 2015 did not follow the same trend observed in 2014 and differences between control and fertilized plots and among fertilized plots were presented.

The aboveground biomass was not significantly affected in 2014; however in 2015, the treatments receiving no $\mathrm{N}$ fertilizer presented the lowest value (Table 6). In 2015, the aboveground biomass showed to be statistically responsive to the increasing $\mathrm{N}$ rates, which is commonly found in the literature $[46,47]$.

Hagedorn et al. [48] mentioned that, in years with heavy rains, the mineral $\mathrm{N}$ content in the topsoil decrease by 50-70\%; however, in low rainfall seasons, the pronounced mineralization occurs but the mineral $\mathrm{N}$ decreases only slightly. Therefore, the low rainfall in 2013 may have contributed to the no statistical differences in the fertilized plots 


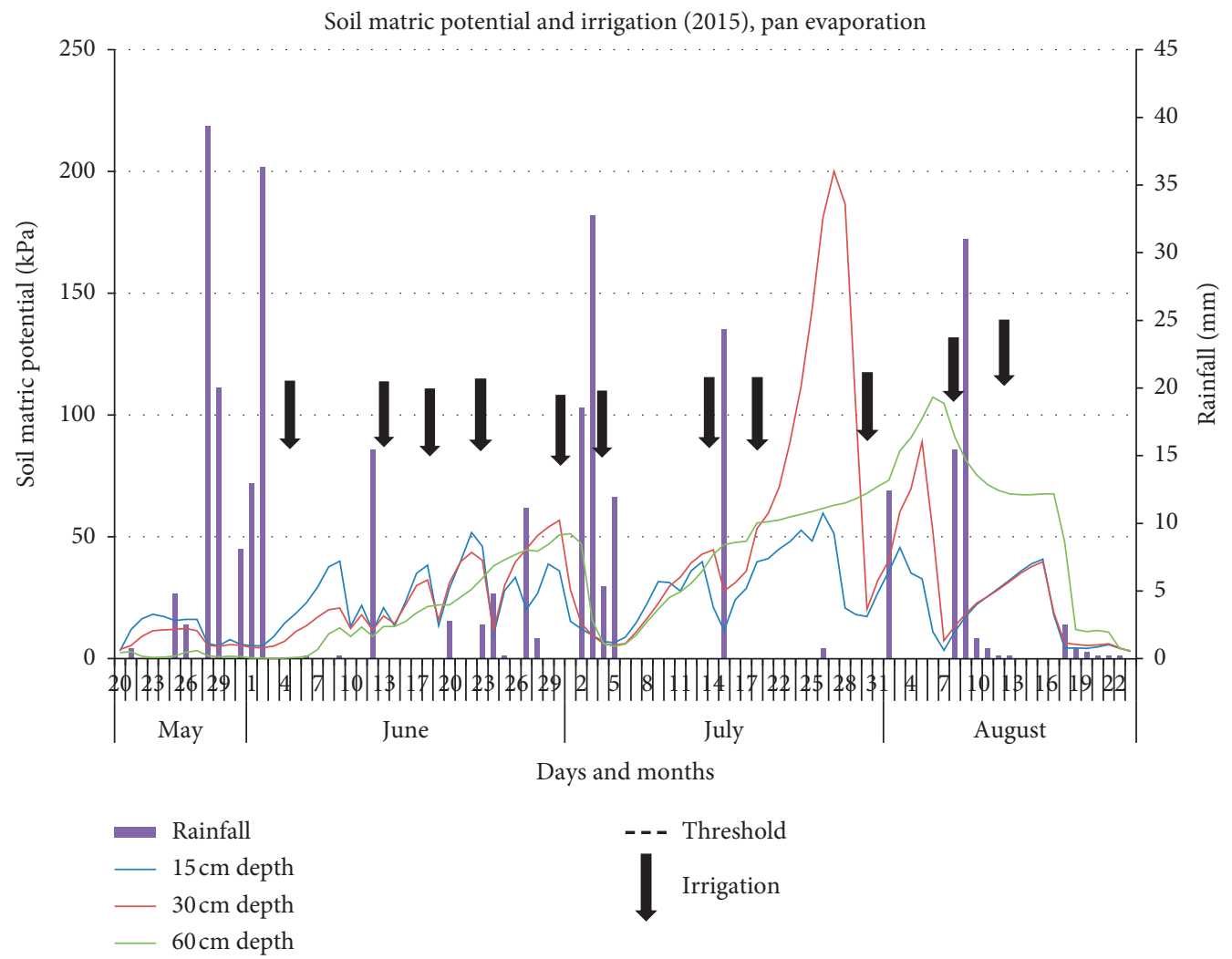

FIGURE 2: Daily soil matric potential in the pan evaporation plot fertilized with $269 \mathrm{~kg} \mathrm{~N} \mathrm{ha}^{-1}$ in 2015 at TVREC. The amount of irrigation referred to in the black arrows was value between 15 and $25 \mathrm{~mm}$ to avoid runoff.

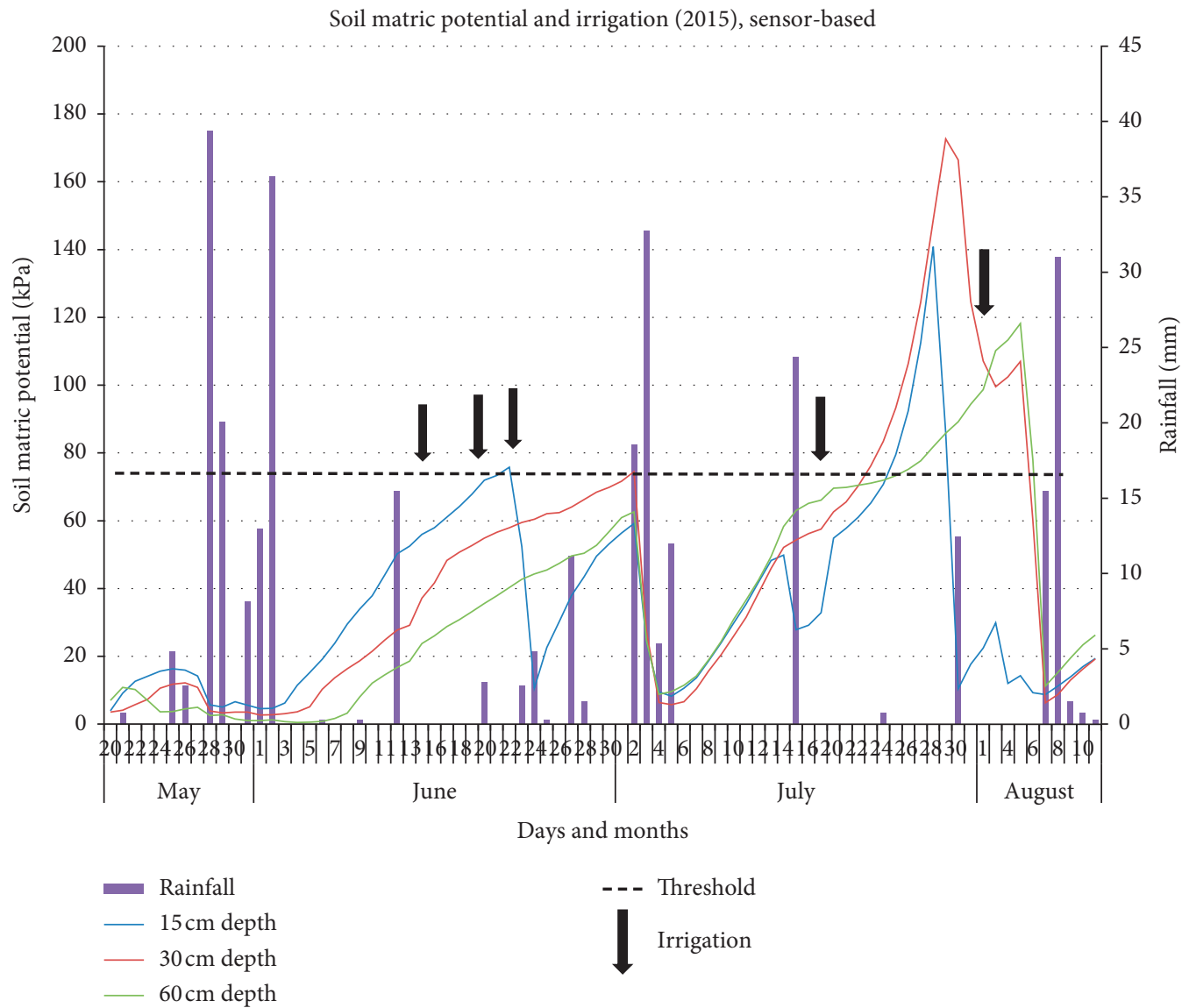

FIGURE 3: Daily soil matric potential in the sensor-based plot fertilized with $269 \mathrm{~kg} \mathrm{Nha}^{-1}$ in 2015 at TVREC. The amount of irrigation referred to in the black arrows was value between 15 and $25 \mathrm{~mm}$ to avoid runoff. 
TABLE 5: Summary of ANOVA for grain yield, aboveground biomass, $\mathrm{N}$ uptake, and NUE with respect to $\mathrm{N}$ rates $\left(0,202,269\right.$, and $336 \mathrm{~kg}$ ha $\left.{ }^{-1}\right)$, irrigation, and years (2014-2015) at TVREC.

\begin{tabular}{|c|c|c|c|c|c|c|c|c|c|c|}
\hline \multirow{2}{*}{$\begin{array}{l}\text { Sources of } \\
\text { variation }\end{array}$} & \multirow{2}{*}{$\begin{array}{c}\text { Grain } \\
\text { yield } \\
\left(\mathrm{Mg} \mathrm{ha}^{-1}\right) \\
\end{array}$} & \multirow{2}{*}{$\begin{array}{c}\text { Aboveground } \\
\text { biomass } \\
\left(\mathrm{Mg} \mathrm{ha}^{-1}\right) \\
\end{array}$} & \multirow{2}{*}{$\begin{array}{c}\text { Grain } \mathrm{N} \\
\text { concentration } \\
\left(\mathrm{g} \mathrm{kg}^{-1}\right)\end{array}$} & \multirow{2}{*}{$\begin{array}{c}\text { Stover } \mathrm{N} \\
\text { concentration } \\
\left(\mathrm{g} \mathrm{kg}^{-1}\right)\end{array}$} & \multirow{2}{*}{$\begin{array}{c}\text { Grain N } \\
\text { uptake } \\
\left(\mathrm{g} \mathrm{kg}^{-1}\right)\end{array}$} & \multirow{2}{*}{$\begin{array}{l}\text { Aboveground } \\
\mathrm{N} \text { uptake } \\
\left(\mathrm{kg} \mathrm{Nha}^{-1}\right) \\
\end{array}$} & \multicolumn{4}{|c|}{ Nitrogen use efficiency } \\
\hline & & & & & & & $\mathrm{AEn}^{\ddagger}$ & $\mathrm{REn}^{\S}$ & IEn & $\mathrm{PFPn}^{\#}$ \\
\hline $\begin{array}{l}\text { Irrigation } \\
\text { (I) }\end{array}$ & $\mathrm{Ns}^{\mathcal{E}}$ & Ns & Ns & Ns & Ns & Ns & Ns & $P<0.05$ & Ns & Ns \\
\hline $\mathrm{N}$ rate $(\mathrm{N})$ & $P<0.05 *$ & $\mathrm{Ns}$ & Ns & Ns & $\mathrm{N}$ & $P<0$. & $P<0.05$ & $N$ & $N_{s}$ & $P<0.05$ \\
\hline Year (Y) & $P<0.05$ & $\mathrm{~N}$ & $P<0.0$ & $P<0.0$ & $\mathrm{~N}$ & $P<0.0$ & $P<0.05$ & $P<0.05$ & $P<0.05$ & $P<0.05$ \\
\hline $\mathrm{I} \times \mathrm{N}$ & Ns & Ns & Ns & Ns & Ns & Ns & Ns & Ns & Ns & Ns \\
\hline $\mathrm{YxN}$ & $P<0.05$ & Ns & Ns & Ns & Ns & $P<0.0$ & $P<0.05$ & Ns & Ns & $P<0.05$ \\
\hline Yx I & Ns & Ns & Ns & Ns & $\mathrm{N}$ & Ns & Ns & $P<0.05$ & Ns & Ns \\
\hline YxIxN & Ns & Ns & Ns & Ns & Ns & Ns & Ns & Ns & Ns & Ns \\
\hline
\end{tabular}

${ }^{*}$ Significant at 0.05 probability level. ${ }^{\mathfrak{E}}$ Nonsignificant at 0.05 probability level. ${ }^{\ddagger}$ AEn: nitrogen agronomy efficiency. ${ }^{\varsigma}$ REn: recovery efficiency. ${ }^{\circledR}$ IEn: nitrogen internal efficiency. ${ }^{*} \mathrm{PFPn}$ : nitrogen partial productivity.

TABLE 6: Grain yield and aboveground biomass differences between years and N rates $\left(0,202,269\right.$, and $\left.336 \mathrm{~kg} \mathrm{ha}^{-1}\right)$ at the TVREC.

\begin{tabular}{|c|c|c|c|c|c|c|}
\hline \multirow{3}{*}{$\mathrm{N}$ rate ( $\mathrm{kg} \mathrm{ha)}$} & \multicolumn{4}{|c|}{ Grain yield $\left(\mathrm{Mg} \mathrm{ha}^{-1}\right)$} & \multirow{2}{*}{\multicolumn{2}{|c|}{$\begin{array}{c}\text { Aboveground biomass } \\
\left(\mathrm{Mg} \mathrm{ha}^{-1}\right) \\
2015\end{array}$}} \\
\hline & \multicolumn{2}{|c|}{2014} & \multicolumn{2}{|c|}{2015} & & \\
\hline & Mean & $\mathrm{SE}^{\neq}$ & Mean & SE & Mean & SE \\
\hline 0 & $7.62^{\mathrm{b} \varsigma}$ & 0.52 & $5.52^{c}$ & 0.36 & $12.56^{\mathrm{b}}$ & 0.79 \\
\hline 202 & $13.53^{\mathrm{a}}$ & 0.52 & $12.54^{\mathrm{b}}$ & 0.36 & $15.79^{a}$ & 0.79 \\
\hline 269 & $14.23^{\mathrm{a}}$ & 0.52 & $13.22^{\mathrm{ba}}$ & 0.36 & $14.65^{\mathrm{ba}}$ & 0.79 \\
\hline 336 & $13.80^{\mathrm{a}}$ & 0.52 & $13.81^{\mathrm{a}}$ & 0.36 & $17.18^{\mathrm{a}}$ & 0.79 \\
\hline
\end{tabular}

${ }^{\mp}$ Standard error. ${ }^{\varsigma}$ Numbers at the same column followed by the same letter are nonsignificant at $P<0.05$.

in 2014. The 2013 season received $50 \%$ less precipitation than the normal of 30 years normal (Table 3 ). Furthermore, residual mineral $\mathrm{N}$ may have increase because leaching was limited due to low rainfall in 2013 and it could explain the low corn yield responses to $\mathrm{N}$ application observed in 2014. Extra $\mathrm{N}$ in 2014 could also explain why control plots in 2014 obtained higher yields than 2015.

The impact of $\mathrm{N}$ rate on grain yield is important because of its effect on production profitability. Therefore, if the $\mathrm{N}$ fertilizer investment does not translate into a yield increase, then excess $\mathrm{N}$ could cause environmental problems. Some studies in this area suggest that increasing $\mathrm{N}$ application above optimal rates will lead to only small increases or even decreases in the grain yield and aboveground biomass. However, it may cause an increase in the energy use and production costs as well as increasing the risk of negative environmental effects such as greenhouse gas emission, soil acidification, and nitrate leaching [49-51].

3.5. Variation in Corn N Concentration. Grain and stover $\mathrm{N}$ concentrations were different between the two growing seasons with the $\mathrm{N}$ concentration values in 2015 greater than the values observed in 2014 (Table 7). Overall, grain and stover $\mathrm{N}$ concentration increased as the $\mathrm{N}$ rate increased (Table 7). During the two growing seasons, grain $\mathrm{N}$ concentration ranged from $8.75 \mathrm{~g} \mathrm{~kg}^{-1}$ to $14.00 \mathrm{~g} \mathrm{~kg}^{-1}$ and the stover $\mathrm{N}$ concentration ranged from $0.61 \mathrm{~g} \mathrm{~kg}^{-1}$ to $13.23 \mathrm{~g} \mathrm{~kg}^{-1}$. Overall, grain and stover $\mathrm{N}$ concentration increased as the $\mathrm{N}$ rate increased (Table 7). Ciampitti and $\mathrm{Vyn}$ [52] reported the $\mathrm{N}$ concentration range for the new era corn cultivars was $3.0 \mathrm{~g} \mathrm{~kg}^{-1}$ to $26.8 \mathrm{~g} \mathrm{~kg}$ and $1.2 \mathrm{~g} \mathrm{~kg}^{-1}$ to $21.1 \mathrm{~g} \mathrm{~kg}^{-1}$ for grain and stover, respectively. Setiyono et al. [53] also reported large variation of $\mathrm{N}$ concentration values in corn plants across several studies; therefore this may explain the oscillation of $\mathrm{N}$ concentration in 2014 and 2015.

In 2014, yields were higher which indicates that plants were able to use the applied $\mathrm{N}$. Therefore, the $\mathrm{N}$ dilution could occur because higher yields and more biomass may reduce an equivalent $\mathrm{N}$ concentration in the plant in 2014. Moreover, temperature could be another reason of the increase of $\mathrm{N}$ concentration in the corn plants. Wienhold et al. [54] compared $\mathrm{N}$ concentration in corn and obtained $75 \%$ higher $\mathrm{N}$ content values in years when the temperature was above the 30 -year average. Therefore, higher temperature in 2015 (Table 3) could explain the increase of $\mathrm{N}$ concentration for this growing season.

In 2015, grain $\mathrm{N}$ concentration differences between the control and fertilized treatments were smaller than the differences observed in the 2014 growing season. Therefore, in 2015 the corn plants uptake more $\mathrm{N}$ from the unfertilized plots, showing the ability of corn to uptake nitrogen from the soil $\mathrm{N}$ pools even when no $\mathrm{N}$ fertilizer is applied (Table 7). In $2014, \mathrm{~N}$ rate did not affect the $\mathrm{N}$ concentration in the stover, but in 2015, stover $\mathrm{N}$ concentration increased following increment of nitrogen fertilizer.

Aboveground $\mathrm{N}$ uptake ranged from $125.43 \mathrm{~kg} \mathrm{~N} \mathrm{ha}^{-1}$ to $421.64 \mathrm{~kg} \mathrm{~N} \mathrm{ha}^{-1}$ during the two growing seasons. Ciampitti and Vyn [49] reported the mean, minimum, and maximum 
TABLE 7: Grain N, stover N concentrations and grain, and aboveground $\mathrm{N}$ uptake differences between years and $\mathrm{N}$ rates $(0,202,269$, and $336 \mathrm{~kg} \mathrm{ha}^{-1}$ ) at TVREC.

\begin{tabular}{|c|c|c|c|c|c|c|c|c|c|c|c|c|}
\hline \multirow{3}{*}{$\mathrm{N}$ rate $\left(\mathrm{kg} \mathrm{ha}^{-1}\right)$} & \multicolumn{4}{|c|}{ Grain $\mathrm{N}$ concentration $\left(\mathrm{g} \mathrm{kg}^{-1}\right)$} & \multicolumn{4}{|c|}{ Stover $\mathrm{N}$ concentration $\left(\mathrm{g} \mathrm{kg}^{-1}\right)$} & \multicolumn{4}{|c|}{ Aboveground $\mathrm{N}$ uptake $\left(\mathrm{kg} \mathrm{N} \mathrm{ha}^{-1}\right)$} \\
\hline & \multicolumn{2}{|c|}{2014} & \multicolumn{2}{|c|}{2015} & \multicolumn{2}{|c|}{2014} & \multicolumn{2}{|c|}{2015} & \multicolumn{2}{|c|}{2014} & \multicolumn{2}{|c|}{2015} \\
\hline & Mean & $\mathrm{SE}^{\neq}$ & Mean & SE & Mean & SE & Mean & SE & Mean & SE & Mean & SE \\
\hline 0 & $8.75^{\mathrm{b} \S}$ & 0.66 & $11.70^{c}$ & 0.21 & $0.61^{\mathrm{a}}$ & 1.68 & $8.11^{\mathrm{b}}$ & 0.87 & $125.43^{\mathrm{b}}$ & 22.03 & $166.68^{c}$ & 39.03 \\
\hline 202 & $10.53^{\mathrm{a}}$ & 0.66 & $12.52^{\mathrm{b}}$ & 0.21 & $3.05^{\mathrm{a}}$ & 1.68 & $10.50^{\text {ba }}$ & 0.87 & $216.55^{\mathrm{a}}$ & 22.03 & $321.68^{\mathrm{b}}$ & 39.03 \\
\hline 269 & $11.10^{\mathrm{a}}$ & 0.66 & $13.51^{\mathrm{a}}$ & 0.21 & $1.15^{\mathrm{a}}$ & 1.68 & $12.16^{\mathrm{a}}$ & 0.87 & $230.51^{\mathrm{a}}$ & 22.03 & $351.36^{\mathrm{ba}}$ & 39.03 \\
\hline 336 & $11.54^{\mathrm{a}}$ & 0.66 & $14.00^{\mathrm{a}}$ & 0.21 & $2.45^{\mathrm{a}}$ & 1.68 & $13.23^{\mathrm{a}}$ & 0.87 & $241.79^{\mathrm{a}}$ & 22.03 & $421.64^{\mathrm{a}}$ & 39.03 \\
\hline
\end{tabular}

${ }^{\ddagger}$ Standard error. ${ }^{\S}$ Numbers at the same column followed by the same letter are nonsignificant at $P<0.05$.

$\mathrm{N}$ uptake of new era maize cultivars and the values were 184, 2 , and $427 \mathrm{~kg} \mathrm{~N} \mathrm{ha}^{-1}$, respectively. Other numbers reported by Setiyono et al. [53] showed 239, 7, and $471 \mathrm{~kg} \mathrm{~N} \mathrm{ha}^{-1}$ as mean, minimum, and maximum, respectively. Therefore, the maximum and minimum $\mathrm{N}$ uptake values obtained in Alabama's environment in this present study agreed with the range of new era cultivars reported by other authors. Aboveground $\mathrm{N}$ uptake was higher in 2015 when compared to 2014. In 2014, the aboveground $\mathrm{N}$ uptake between control and fertilized treatments was statistically significant; however considering only the fertilized treatments, the $\mathrm{N}$ uptake values increased numerically but these differences were not significant (Table 7). During the season of 2015, the aboveground $\mathrm{N}$ uptake increased significantly with the increase of $\mathrm{N}$ rate (Table 7). Abbasi et al. [55] reported that aboveground $\mathrm{N}$ uptake increased with $\mathrm{N}$ rate; therefore in our study, the $\mathrm{N}$ uptake increased as the $\mathrm{N}$ rate increased but the increment was not significant in all cases.

Setiyono et al. [53] and Chua et al. [56] reported that aboveground $\mathrm{N}$ uptake has been closely linked with grain and aboveground biomass. However, we observed that, in general, grain yield was higher in 2014 but the overall aboveground $\mathrm{N}$ uptake was lower when comparing with 2015. Herrmann and Taube [57] found lower $N$ uptake in higher corn biomass yield and it might be due the $\mathrm{N}$ dilution because the $\mathrm{N}$ is spread out in the plant tissue.

Furthermore, other studies evidenced that aboveground $\mathrm{N}$ uptake is not proportionately linked with grain yield. Jokela and Randall [58] presented some data from a threeyear study (1982-1984) comparing grain yield and aboveground $\mathrm{N}$ uptake and found years with higher yield and lower $\mathrm{N}$ uptake or vice versa. Uribelarrea et al. [59] compared four commercial corn hybrids in three years and also found higher yield and lower $\mathrm{N}$ uptake; furthermore, some hybrids had a negative $\mathrm{N}$ balance removing more $\mathrm{N}$ than was applied as fertilizer-N. It also occurred in our study in the 2015 growing season (Table 7).

3.6. Nitrogen Use Efficiency. The Nitrogen Use Efficiency (NUE) increase indicates that most $\mathrm{N}$ fertilizer applied in the soil was taken up by plants and converted into grain yield. Therefore, the amount of $\mathrm{N}$ that remains in the soil is lower decreasing the potential of leaching and can effectively decrease the potential negative impacts of $\mathrm{N}$ fertilizer to the environment $[55,60]$.

The $\mathrm{AE}_{\mathrm{n}}$ and $\mathrm{PFP}_{\mathrm{n}}$ followed the same trend in 2014 and 2015; higher $\mathrm{AE}_{\mathrm{n}}$ and $\mathrm{PFP}_{\mathrm{n}}$ were observed for the treatment fertilized with $202 \mathrm{~kg} \mathrm{Nha}^{-1}$ and gradually decreased as $\mathrm{N}$ rate increased (Table 8 ). Also, the lowest NUE value was observed from the plots fertilized with the highest $\mathrm{N}$ rate $\left(336 \mathrm{~kg} \mathrm{~N} \mathrm{ha}^{-1}\right)$. According to Ciampitti and Vyn [60], it is well accepted the NUEs values are high at low $\mathrm{N}$ rates and decrease with increasing $\mathrm{N}$ rates. Furthermore, $\mathrm{AE}_{\mathrm{n}}$ and $\mathrm{PFP}_{\mathrm{n}}$ may be more practical parameters because grain yield and $\mathrm{N}$ rate are used in the equation; therefore they are easier parameters to be calculated by farmers. The $\mathrm{RE}_{\mathrm{n}}$ and $\mathrm{IE}_{\mathrm{n}}$ did not present significant differences during both seasons. Also considering that these parameters use aboveground $\mathrm{N}$ uptake in the equation, it might be more laborious for the farmers because it is necessary to do the $\mathrm{N}$ concentration analysis.

Considering the values obtained in 2014 and $2015, \mathrm{RE}_{\mathrm{n}}$ decreased from 98.03 to $35.61, \mathrm{AE}_{\mathrm{n}}$ from 36.32 to $16.78 \mathrm{~kg} \mathrm{~kg}^{-1}, \mathrm{IE}_{\mathrm{n}}$ from 63.64 to $33.94 \mathrm{~kg} \mathrm{~kg}^{-1}$, and $\mathrm{PFP}_{\mathrm{n}}$ from 67.96 to $39.56 \mathrm{~kg} \mathrm{~kg}^{-1}$ and, in most of the cases, the value decreased due increasing $\mathrm{N}$ rate. Ciampitti and Vyn [60] reported that the mean values of $\mathrm{RE}_{n}, \mathrm{AE}_{\mathrm{n}}, \mathrm{IE}_{\mathrm{n}}$, and $\mathrm{PFP}_{\mathrm{n}}$ for new era hybrid corn were 44\%, 22.9, 55.0, and $66.0 \mathrm{~kg} \mathrm{~kg}^{-1}$, respectively. In general, all NUE parameters from 2014 were similar or comparable to the mean values of the new era corn hybrid. However, in $2015, \mathrm{RE}_{\mathrm{n}}$ values were high especially in the pan evaporation treatments and the $\mathrm{IE}_{\mathrm{n}}$ values were low (Table 8).

High $\mathrm{RE}_{\mathrm{n}}$ values in 2015 may be attributed to increased aboveground $\mathrm{N}$ uptake; however, control treatments had lower $\mathrm{N}$ uptake values compared to fertilized treatments (Table 8). Therefore, $\mathrm{N}$ uptake differences between control and fertilized treatments were higher in 2015; consequently, this increased the $\mathrm{RE}_{\mathrm{n}}$ values for 2015. Lower $\mathrm{IE}_{\mathrm{n}}$ values in 2015 can be explained by the high aboveground $\mathrm{N}$ uptake values.

The NUEs equations are simple; however, they depend on several parameters, which may or may not be controlled by producers, for example, $\mathrm{N}$ rate or weather conditions, respectively. Therefore, there is potential to improve NUE and minimize negative environmental impacts if optimum practices for soil management, agronomy, ecology, and genetics are adopted with sustainable agriculture [52, 61]. 
TABLE 8: Nitrogen recovery efficiency $\left(\mathrm{RE}_{n}\right)$, nitrogen agronomic efficiency $\left(\mathrm{AE}_{\mathrm{n}}\right)$, nitrogen internal efficiency ( $\left.\mathrm{IE}_{n}\right)$, and nitrogen partial productivity $\left(\mathrm{PFP}_{\mathrm{n}}\right)$ at four $\mathrm{N}$ rates $\left(0,202,269\right.$, and $\left.280 \mathrm{~kg} \mathrm{Nha}^{-1}\right)$ in 2014 and 2015 at TVREC.

\begin{tabular}{|c|c|c|c|c|c|c|c|c|c|c|c|c|c|c|c|c|}
\hline \multirow{3}{*}{$\mathrm{N}$ rate $\left(\mathrm{kg} \mathrm{ha}^{-1}\right)$} & \multicolumn{4}{|c|}{$\operatorname{REn}(\%)^{\ddagger}$} & \multicolumn{4}{|c|}{$\operatorname{AEn}\left(\mathrm{kg} \mathrm{kg}^{-1}\right)^{\S}$} & \multicolumn{4}{|c|}{ IEn $\left(\mathrm{kg} \mathrm{kg}^{-1}\right)^{9}$} & \multicolumn{4}{|c|}{ PFPn $\left(\mathrm{kg} \mathrm{kg}^{-1}\right)^{\#}$} \\
\hline & \multicolumn{2}{|c|}{2014} & \multicolumn{2}{|c|}{2015} & \multicolumn{2}{|c|}{2014} & \multicolumn{2}{|c|}{2015} & \multicolumn{2}{|c|}{2014} & \multicolumn{2}{|c|}{2015} & \multicolumn{2}{|c|}{2014} & \multicolumn{2}{|c|}{2015} \\
\hline & Mean & SE $\neq$ & Mean & SE & Mean & SE & Mean & SE & Mean & SE & Mean & SE & Mean & SE & Mean & SE \\
\hline 0 & $a$ & $a$ & $a$ & $a$ & $a$ & $a$ & $a$ & $a$ & $62.57^{\mathrm{a}}$ & 2.38 & $35.04 \mathrm{a}$ & 2.16 & $a$ & $a$ & a & $a$ \\
\hline 202 & $36.94^{\mathrm{a}}$ & 4.44 & $98.03^{\mathrm{a}}$ & 16.79 & $24.96^{\mathrm{a}}$ & 2.79 & $36.32^{\mathrm{a}}$ & 0.67 & $63.64^{\mathrm{a}}$ & 2.38 & $40.38^{\mathrm{a}}$ & 2.16 & $67.96^{\mathrm{a}}$ & 2.59 & $62.33^{\mathrm{a}}$ & 1.82 \\
\hline 269 & $43.96^{\mathrm{a}}$ & 4.44 & $80.27^{\mathrm{a}}$ & 16.79 & $22.7^{\mathrm{a}}$ & 2.79 & $28.79^{\mathrm{b}}$ & 0.67 & $62.76^{\mathrm{a}}$ & 2.38 & $38.16^{\mathrm{a}}$ & 2.16 & $52.32^{\mathrm{b}}$ & 2.59 & $49.32^{\mathrm{b}}$ & 1.82 \\
\hline 336 & $35.61^{\mathrm{a}}$ & 4.44 & $85.58^{\mathrm{a}}$ & 16.79 & $16.78^{\mathrm{b}}$ & 2.79 & $23.62^{\mathrm{c}}$ & 0.67 & $58.37^{\mathrm{a}}$ & 2.38 & $33.94^{\mathrm{a}}$ & 2.16 & $39.56^{\mathrm{c}}$ & 2.59 & $41.22^{\mathrm{c}}$ & 1.82 \\
\hline
\end{tabular}

${ }^{\ddagger}$ Ren: recovery efficiency. ${ }^{\$} \mathrm{AEn}$ : nitrogen agronomy efficiency. ${ }^{9}$ IEn: nitrogen internal efficiency. ${ }^{*} \mathrm{PFPn}$ : nitrogen partial productivity. ${ }^{\mathrm{F}}$ Numbers at the same column followed by the same letter are nonsignificant at $P<0.05$. ${ }^{x}$ Do not apply.

\section{Conclusions}

The sensor-based Irrigation scheduling method tends to have a better performance during the 2014 and 2015 relative to the pan evaporation method. Even though less water was applied using the sensor-based irrigation scheduling method, the differences between the methods might be affected by the lack of irrigation that occurred on both seasons due to the failure of the irrigation pump during the period of high crop water demand. However, the results showed that the sensor-based method was a reliable method to monitor soil water status and provide useful data for producers to manage irrigation scheduling. The pan evaporation method might be less accurate in terms of soil moisture content because it assumes uniform soil conditions and is based on estimations of the soil water balance. When comparing both irrigation scheduling methods tested in this experiment, $29 \%$ more water was applied on average using the pan evaporation irrigation scheduling method compared to the sensor-based method. Despite these differences, there were no significant grain yields or aboveground biomass differences observed between the two irrigation scheduling methods. Moreover, the lack of water application caused by the problems in the irrigation pump may have affected the yield potential of grain and aboveground biomass; thus no significant differences were presented. Nitrogen rates evaluated in this study affected grain yield, aboveground $\mathrm{N}$ uptake, and NUE expressed as $\mathrm{AE}_{n}$ and $\mathrm{PFP}_{\mathrm{n}}$. In general, NUEs values decreased with an increase in $\mathrm{N}$ rates, which means that extra $\mathrm{N}$ fertilizer added to the soil was not converted into grain yield or/and uptake by plants, which might increase the risk of future environmental problems.

\section{Data Availability}

The data used to support the findings of this study are available from the corresponding author upon request.

\section{Disclosure}

This research is part of a Master of Science Thesis called "Evaluation of Irrigation Scheduling Methods and Nitrogen Fertilization Effect on Corn Production in Alabama" [62].

\section{Conflicts of Interest}

The authors declare no conflicts of interest.

\section{Acknowledgments}

This research was financed by the Department of Crop, Soil and Environmental Sciences, Auburn University.

\section{References}

[1] A. Arguez, I. Durre, S. Applequist et al., NOAA's US Climate Normals (1981-2010), NOAA National Centers for Environmental Information, Asheville, NC, USA, 2010.

[2] USDA-NASS, Quick Stats, USDA-NASS, Washington, DC, USA, 2016.

[3] C. R. Boomsma and T. J. Vyn, "Maize drought tolerance: potential improvements through arbuscular mycorrhizal symbiosis?" Field Crops Research, vol. 108, no. 1, pp. 14-31, 2008.

[4] Y. Jiao, P. Peluso, and J. Shi, "Improved maize reference genome with single-molecule technologies," Nature, vol. 546, no. 7659, pp. 524-527, 2017.

[5] S. J. Qiu, P. He, S. C. Zhao et al., "Impact of nitrogen rate on maize yield and nitrogen use efficiencies in northeast China," Agronomy Journal, vol. 107, no. 1, pp. 305-313, 2015.

[6] K. P. Woli, M. J. Boyer, R. W. Elmore, J. E. Sawyer, L. J. Abendroth, and D. W. Barker, "Corn era hybrid response to nitrogen fertilization," Agronomy Journal, vol. 108, no. 2, pp. 473-486, 2016.

[7] L. S. Pereira, T. Oweis, and A. Zairi, "Irrigation management under water scarcity," Agricultural Water Management, vol. 57, no. 3, pp. 175-206, 2002.

[8] C. Kirda, "Deficit irrigation scheduling based on plant growth stages showing water stress tolerance," Food and Agricultural Organization of the United Nations, Deficit Irrigation Practices, Water Reports, vol. 22, no. 102, 2002.

[9] A. Fares and A. K. Alva, "Evaluation of capacitance probes for optimal irrigation of citrus through soil moisture monitoring in an entisol profile," Irrigation Science, vol. 19, no. 2, pp. 57-64, 2000.

[10] C. Phene and T. Howell, "Soil sensor control of high-frequency irrigation systems," Transactions of the ASAE, vol. 27, no. 2, pp. 392-396, 1984.

[11] G. Stanhill, "Is the Class A evaporation pan still the most practical and accurate meteorological method for determining irrigation water requirements?" Agricultural and Forest Meteorology, vol. 112, no. 3-4, pp. 233-236, 2002.

[12] J. Bruton, R. McClendon, and G. Hoogenboom, "Estimating daily pan evaporation with artificial neural networks," Transactions of the ASAE, vol. 43, no. 2, pp. 491-496, 2000.

[13] L. S. Pereira, "Higher performance through combined improvements in irrigation methods and scheduling: a 
discussion," Agricultural Water Management, vol. 40, no. 2-3, pp. 153-169, 1999.

[14] M. M. Shaahan, A. A. El-Sayed, and E. A. A. Abou El-Nour, "Predicting nitrogen, magnesium and iron nutritional status in some perennial crops using a portable chlorophyll meter," Scientia Horticulturae, vol. 82, no. 3-4, pp. 339-348, 1999.

[15] K. P. Fabrizzi, F. O. Garća, J. L. Costa, and L. I. Picone, "Soil water dynamics, physical properties and corn and wheat responses to minimum and no-tillage systems in the southern Pampas of Argentina," Soil and Tillage Research, vol. 81, no. 1, pp. 57-69, 2005.

[16] H. V. Eck, "Irrigated corn yield response to nitrogen and water," Agronomy Journal, vol. 76, no. 3, pp. 421-428, 1984.

[17] W. J. Cox, S. Kalonge, D. J. R. Cherney, and W. S. Reid, "Growth, yield, and quality of forage maize under different nitrogen management practices," Agronomy Journal, vol. 85, no. 2, pp. 341-347, 1993.

[18] R. Novoa and R. S. Loomis, "Nitrogen and plant production," Soil Water and Nitrogen in Mediterranean-type Environments, vol. 58, no. 1-3, pp. 177-204, 1981.

[19] V. R. Tóth, I. Mészáros, S. Veres, and J. Nagy, "Effects of the available nitrogen on the photosynthetic activity and xanthophyll cycle pool of maize in field," Journal of Plant Physiology, vol. 159, no. 6, pp. 627-634, 2002.

[20] M. Uribelarrea, S. J. Crafts-Brandner, and F. E. Below, "Physiological N response of field-grown maize hybrids (Zea mays L.) with divergent yield potential and grain protein concentration," Plant and Soil, vol. 316, no. 1-2, p. 151, 2009.

[21] K. Djaman, S. Irmak, D. L. Martin, R. B. Ferguson, and M. L. Bernards, "Plant nutrient uptake and soil nutrient dynamics under full and limited irrigation and rainfed maize production," Agronomy Journal, vol. 105, no. 2, pp. 527-538, 2013.

[22] B. Eghball and J. W. Maranville, "Root development and nitrogen influx of corn genotypes grown under combined drought and nitrogen stresses," Agronomy Journal, vol. 85, no. 1, pp. 147-152, 1993.

[23] Y. Liu, J. Li, and Y. Li, "Effects of split fertigation rates on the dynamics of nitrate in soil and the yield of mulched dripirrigated maize in the sub-humid region," Applied Engineering in Agriculture, vol. 31, no. 1, pp. 103-117, 2015.

[24] A. Montazar and B. Azadegan, "Effects of seasonal water use and applied n fertilizer on wheat water productivity indices," Irrigation and Drainage, vol. 61, no. 1, pp. 52-59, 2012.

[25] A. V. Széles, A. Megyes, and J. Nagy, "Irrigation and nitrogen effects on the leaf chlorophyll content and grain yield of maize in different crop years," Agricultural Water Management, vol. 107, pp. 133-144, 2012.

[26] J. Lauer, "What happens within the corn plant when drought occurs," Corn Agronomist, vol. 10, no. 22, pp. 153-155, 2003.

[27] H. C. H. Hahne, W. Kroontje, and J. A. Lutz Jr., "Nitrogen fertilization I. Nitrate accumulation and losses under continuous corn cropping," Soil Science Society of America Journal, vol. 41, no. 3, pp. 562-567, 1977.

[28] USDA and NRCS, Web Soil Survey, https://websoilsurvey.sc. egov.usda.gov/App/HomePage.htm, 2011.

[29] C. C. Mitchell and G. Huluka, Nutrient Recommendation Tables for Alabama Crops, Auburn University, Auburn, AL, USA, 2012.

[30] R. L. Snyder, "Equation for evaporation pan to evapotranspiration conversions," Journal of Irrigation and Drainage Engineering, vol. 118, no. 6, pp. 977-980, 1992.
[31] J. R. Eagleman, "Pan evaporation, potential and actual evapotranspiration," Journal of Applied Meteorology, vol. 6, no. 3, pp. 482-488, 1967.

[32] G. Vellidis, M. Tucker, C. Perry, C. Kvien, and C. Bednarz, “A real-time wireless smart sensor array for scheduling irrigation," Computers and Electronics in Agriculture, vol. 61, no. 1, pp. 44-50, 2008.

[33] S. J. Thomson and C. Fletcher Armstrong, "Calibration of the Watermark model 200 soil moisture sensor," Applied Engineering in Agriculture, vol. 3, no. 2, pp. 186-189, 1987.

[34] S. J. Thomson, T. Younos, and K. Wood, "Evaluation of calibration equations and application methods for the watermark $^{\circledR}$ granular matrix soil moisture sensor," Applied Engineering in Agriculture, vol. 12, no. 1, pp. 99-103, 1996.

[35] W. Bausch and T. Bernard, "Validity of the watermark sensor as a soil moisture measuring device," "Validity of the watermark sensor as a soil moisture measuring device," in Proceedings of the Intelligence Conference Evapotranspiration and Irrigation Scheduling. CR Camp, E. J. Sadler and R. E. Yoder, Eds., ASAE, St. Joseph, MI, USA, 1996.

[36] A. R. Mitchell and C. C. Shock, "A watermark datalogging system for ET measurement," "A watermark datalogging system for ET measurement," in Proceedings of the Intelligence Conference Evapotranspiration and Irrigation Scheduling. CR Camp, E. J. Sadler and R. E. Yoder, Eds., ASAE, St. Joseph, MI, USA, 1996.

[37] R. G. Evans, "Precision center pivot irrigation for efficient use of water and nitrogen," in Proceedings of the Third International Conference on Precision Agriculture, Minneapolis, MN, USA, 1996.

[38] F. Lamm, D. Rogers, and H. Manges, "Irrigation scheduling with planned soil water depletion," Transactions of the ASAE, vol. 37, no. 5, pp. 1491-1497, 1994.

[39] J. Doorenbos and W. Pruitt, "Crop water requirements," FAO, 1977pp. 34-37, FAO, Rome, Italy, FAO Irrigation and Drainage Paper No. 24.

[40] S. Irmak, M. J. Burgert, H. S. Yang et al., "Large-scale on-farm implementation of soil moisture-based irrigation management strategies for increasing maize water productivity," Transactions of the ASABE, vol. 55, no. 3, pp. 881-894, 2012.

[41] K. E. Saxton, W. J. Rawls, J. S. Romberger, and R. I. Papendick, "Estimating generalized soil-water characteristics from texture," Soil Science Society of America Journal, vol. 50, no. 4, pp. 1031-1036, 1986.

[42] M. T. Van Genuchten, "A closed-form equation for predicting the hydraulic conductivity of unsaturated soils," Soil Science Society of America Journal, vol. 44, no. 5, pp. 892-898, 1980.

[43] L. Richards and L. Weaver, "Moisture retention by some irrigated soils as related to soil moisture tension," Journal of Agricultural Research, vol. 69, no. 6, pp. 215-235, 1944.

[44] E. C. A. Runge, "Effects of rainfall and temperature interactions during the growing season on corn yield," Agronomy Journal, vol. 60, no. 5, pp. 503-507, 1968.

[45] K. M. Glass, C. D. Monks, D. P. Delaney, and J. Brasher, Performance of Field Corn Hybrids in Alabama, Auburn University, Auburn, AL, USA, 2015.

[46] E. Di Paolo and M. Rinaldi, "Yield response of corn to irrigation and nitrogen fertilization in a Mediterranean environment," Field Crops Research, vol. 105, no. 3, pp. 202-210, 2008.

[47] C. A. Shapiro and C. S. Wortmann, "Corn response to nitrogen rate, row spacing, and plant density in eastern Nebraska," Agronomy Journal, vol. 98, no. 3, pp. 529-535, 2006. 
[48] F. Hagedorn, K. G. Steiner, L. Sekayange, and W. Zech, "Effect of rainfall pattern on nitrogen mineralization and leaching in a green manure experiment in South Rwanda," Plant and Soil, vol. 195 , no. 2, pp. 365-375, 1997.

[49] I. A. Ciampitti and T. J. Vyn, "Grain nitrogen source changes over time in maize: a review," Crop Science, vol. 53, no. 2, pp. 366-377, 2013.

[50] J. H. Guo, X. J. Liu, Y. Zhang et al., "Significant acidification in major Chinese croplands," Science, vol. 327, no. 5968, pp. 1008-1010, 2010.

[51] X.-T. Ju, G.-X. Xing, X.-P. Chen et al., "Reducing environmental risk by improving $\mathrm{N}$ management in intensive Chinese agricultural systems," Proceedings of the National Academy of Sciences, vol. 106, no. 9, pp. 3041-3046, 2009.

[52] I. A. Ciampitti and T. J. Vyn, "Erratum to: "Physiological perspectives of changes over time in maize yield dependency on nitrogen uptake and associated nitrogen efficiencies: a review" [Field Crops Res. 133 (2012) 48-67]," Field Crops Research, vol. 137, p. 202, 2012.

[53] T. D. Setiyono, D. T. Walters, K. G. Cassman, C. Witt, and A. Dobermann, "Estimating maize nutrient uptake requirements," Field Crops Research, vol. 118, no. 2, pp. 158-168, 2010.

[54] B. J. Wienhold, T. P. Trooien, and G. A. Reichman, "Yield and nitrogen use efficiency of irrigated corn in the northern great plains," Agronomy Journal, vol. 87, no. 5, pp. 842-846, 1995.

[55] M. K. Abbasi, M. M. Tahir, A. Sadiq, M. Iqbal, and M. Zafar, "Yield and nitrogen use efficiency of rainfed maize response to splitting and nitrogen rates in Kashmir, Pakistan," Agronomy Journal, vol. 104, no. 2, pp. 448-457, 2012.

[56] L. Chuan, P. He, J. Jin et al., "Estimating nutrient uptake requirements for wheat in China," Field Crops Research, vol. 146, pp. 96-104, 2013.

[57] A. Herrmann and F. Taube, "The range of the critical nitrogen dilution curve for maize (Zea mays L.) can be extended until silage maturity," Agronomy Journal, vol. 96, no. 4, pp. 1131-1138, 2004.

[58] W. E. Jokela and G. W. Randall, "Corn yield and residual soil nitrate as affected by time and rate of nitrogen application," Agronomy Journal, vol. 81, no. 5, pp. 720-726, 1989.

[59] M. Uribelarrea, S. P. Moose, and F. E. Below, "Divergent selection for grain protein affects nitrogen use in maize hybrids," Field Crops Research, vol. 100, no. 1, pp. 82-90, 2007.

[60] I. A. Ciampitti and T. J. Vyn, "A comprehensive study of plant density consequences on nitrogen uptake dynamics of maize plants from vegetative to reproductive stages," Field Crops Research, vol. 121, no. 1, pp. 2-18, 2011.

[61] X.-P. Chen, Z.-L. Cui, P. M. Vitousek et al., "Integrated soilcrop system management for food security," Proceedings of the National Academy of Sciences, vol. 108, no. 16, pp. 6399-6404, 2011.

[62] J. F. Da Cunha Leme Filho, "Evaluation of irrigation scheduling methods and nitrogen fertilization effect on corn production in Alabama," Master's thesis, Auburn University, Auburn, AL, USA, 2016. 